\title{
Circular Economy and Corporate Social Responsibility: A Literature Review*
}

\author{
Mara Del Baldo ${ }^{* *}$, Mariapia D'Anghela ${ }^{* * *}$
}

\begin{abstract}
The CE model assures a different approach on the relations between economy, environment and society. The CE concept have been investigated in the recent literature above all in understanding the approaches of businesses towards this new model. The paper presents a short literature review aimed at exploring how the Corporate Social Responsibility (CSR) and (CE) are analysed in literature directing attention on how the companies incorporate the CE concept in their sustainability practices. The work contributes to provide insights on how the companies are integrating the CE activities in CSR practices and shows that a deeper investigation of the topic is needed.
\end{abstract}

Keywords: Circular Economy; Corporate Social Responsibility; Literature Review; Green Economy; Bioeconomy

\section{Circular Economy and the Boundaries with Green Economy and Bioeconomy}

In the last years, the model of Circular Economy (CE), drawing from the ideas of industrial ecology and metabolism triggered in the past decades, is replacing the traditional linear model based on the process "produce, use and dismiss", and is attracting the attention of scholars and practitioners (Kirchherr et al., 2018).

The framing of CE, that has gained popular in the 90's, contemplates that economic actors could avoid negative effects on the environment by redesigning the 'product' life-cycle, with the aim to have minimal input and minimal production of system 'waste' (D'Amato et al., 2017). To achieve this goal, both the organizational supply chain and industrial levels are to be "redesigned" to trigger net reductions (Murray et al., 2015), thus calling for a rethinking of the industrial process "since the underlying idea is the transformation of a certain industry by-product into a resource for a second industry, there is a strong emphasis on inter-sectorial dynamics and cooperation" (D'Amato et al., 2017, p. 717). Accordingly, CE is a wide and emerging concept that is not only based on a better resource and waste management (Stewarth \& Niero, 2018), but the CE model assures a different approach on the relations

\footnotetext{
* The Authors: Del Baldo, M. (corresponding author), D'Anghela, M.: all sections 50\% attributable to each author.

** Associate Professor of Business Administration, University of Urbino Carlo Bo (mara.delbaldo@ uniurb.it)

*** Lecturer in Business Administration, University of Urbino Carlo Bo (mariapia.danghela@ uniurb.it)
}

Edited by: Niccolò Cusano University

ISSN: $1593-0319$

Del Baldo, M., \& D’Anghela, M. (2020). Circular Economy and Corporate Social Responsibility: A Literature Review. Symphonya. Emerging Issues in Management (symphonya.unicusano.it), (1), 7087.

http://dx.doi.org/10.4468/2020.1.06delbaldo.danghela 
between economy, environment and society that, if implemented, can contribute to develop a more harmonic system (Rizos et al., 2015).

The concept of $\mathrm{CE}$ has no a unique definition. Since its inception, different contributions have tried to provide an explanation of the concept itself. Ellen MacArthur Foundation have defined the $\mathrm{CE}$ as a sustainable system "that is restorative or regenerative by intention and design", based on different pillars: the use of renewable sources, re-use and minimizing of the waste through a "better design of materials, products, systems" (Ellen MacArthur Foundation, 2012, p. 7). It is an approach to "sustainable development that does not constrain economic growth" (Scarpellini et al., 2020), and the main objectives of the CE are the diminution of flows of materials and wastes, enhancing efficiency through better use of renewable sources and renewal of natural and social capital (Scarpellini et al., 2020).

Moreover, the concept of CE should not be considered in isolation, since it is linked to - and frequently coupled with - the concepts of Green Economy (GE) and Bioeconomy (BE) (Szekacs, 2017). All three concepts are overlapping and includes elements that are interconnected in sustainability research. The blurred boundaries are attributable to the various interpretations and applications of sustainability avenues (Munda, 1997; Neumayer, 2003) proposed and adopted in research, policy making and in the business context (Murray et al., 2015). All three concepts are currently being mainstreamed in the policymaking and academic debate (D'Amato et al., 2017), sharing the common ideal to reconcile economic, environmental and social goals.

Some authors have identified a hierarchical relation among them (Loiseau et al., 2016) ${ }^{1}$, while others have pointed out their integration ("synergies among the three concepts are found in the way they can supplement each other", D'Amato et al., 2017, p. 725) instead of their substitutability, advocating the need to clarify the reciprocal connections and recognizing intra and inter differences among the three concepts.

However, when considering weak/strong sustainability visions (Neumayer, 2003), all concepts are seen as limited in questioning economic growth (Tomaselli et al., 2017) because none of them is embedded in strong sustainability (Lorek and Fuchs, 2013). Drawing from the analysis carried out by D'Amato et al. (2017) concerning the focus on sustainability dimensions, several salient keywords tied to CE (i.e. waste, energy and recycling) were associated with environmental sustainability, while no explicit reference to the social dimension was found. Moreover, the bibliometric analysis including almost two thousand scientific articles published within the last three decades and the conceptual analysis aimed to identify the sustainability narratives predominant in each concept pointed out that CE literature body is the largest one (with 864 publications), followed by GE (the most popular concept worldwide), while BE is the smallest corpus (D'Amato et al., 2017). The different bodies of literature are characterized by a different geographical distribution, fueled by national, European and global policy development. Despite all three concepts are being consistently researched in Europe, CE plays a prominent role in Chinese literature (particularly in journal devoted to industrial ecology, cleaner production and material flow analysis), while Green Economy (UNEP, 2011) and Bioeconomy are more predominant over CE in Europe and the USA, according to the adoption of specific strategies (Bioeconomy, 2012) and the release of national 
policies (UNEP, 2001; USA, 2012; EC, 2015). Namely, CE literature is embedded in the context of industrial systems, focusing on how resources are used (resourcefocus) and on urban processes, dealing with resource-efficiency, increasing resource productivity and decoupling resource utilization from economic growth (Murray et al., 2015). By contrast, other discourses/topics (i.e. rural development) are not addressed, nor a significant attention is attributed to social and local dynamics.

Within the environmental sustainability discourse, Green Economy is an "umbrella concept", including elements (such as eco-efficiency and renewable sources) from $\mathrm{CE}$ and Bioeconomy concepts. With regard to the social dimension, Green Economy appears more inclusive (comprising, for instance, eco-tourism and education) (D'Amato et al., 2017). National and regional policies attentive to contextual factors fuel the growth of "individual" concepts - often tied to specific sectors - attracting the attention of researchers, businesses and policy makers who "cultivate" and apply these concepts that, in turn, mirror their different assumption, objective, focus, and standpoints, applied to drive their sustainability vision and operationalization.

However, previous contributions have not investigated the extension of the theoretical construct underpinning the concept of $\mathrm{CE}$, Green Economy and Bioeconomic in relation to CSR. Also, the extensive review performed by D'Amato et al. (2017) has not paid a specific attention to CSR, including it as a keyword. Their findings pointed out a weak frame of societal aspects within the $\mathrm{CE}$ and other concepts. Therefore, the present study aims to fill in this gap addressing attention on the concept of $\mathrm{CE}$ in relation to $\mathrm{CSR}$, through a literature review aimed at exploring how the CSR and the model of CE are analysed in literature and directing attention on how the companies incorporate the $\mathrm{CE}$ concept in their sustainability practices. According to previous research, we deem it could be valuable considering $\mathrm{CE}$ and CSR connections rather than as isolated topics, because the complementarity can contribute to better clarify the synergies between CE and CSR and enhance the sustainable trajectory both in theory and practice.

The paper is structured as follows. The next paragraph gives the theoretical framework of this work providing the definitions of CE and CSR concepts. Then, the next session presents the description of the research methodology and introduces the characteristics of the chosen articles. In the succeeding paragraph, the main findings are discussed. Finally, the conclusions and potential research areas to be explored are presented.

\section{Circular Economy and Corporate Social Responsibility: Theoretical Point of View}

A relevant contribution on the meaning and the theoretical construct underpinning the CE concept, is attributable to the work of Kirchherr et al. (2017) that provides a definition based on 144 studies on CE. According to them, defining the CE model just considering the waste and resource management is a limited approach: of course it is based on these activities that are fundamental in order to have better processes (from production to consumption), but CE must be considered as a system that involves all the different actors of the society with the final scope of contributing to "environmental quality, economic prosperity and social equity" (Kirchherr et al., 2017). 
In this context, the CE concept have been investigated in the recent literature above all in understanding the approaches of businesses towards this new model, which interest is growing fast (Stewarth \& Niero, 2018) and the policies at European, national and regional levels, that are important to support this transition. Simultaneously, this change is considered very challenging for the companies that must do a very huge effort in terms of management of different aspects: implementing an approach like this mean to change the lines in the management of stakeholders, financial aspects and a better attention on the regulation in different activities (Stewarth \& Niero, 2018).

The concept of CE is not only related to the economic aspects of the companies, but it is strongly related to the environmental sustainability (Kirchherr et al., 2017).

The most recent studies on the $\mathrm{CE}$ are trying to identify how the different researches on sustainability and responsibility are framed in a CE perspective (Ingulfsvann, 2019). Merli et al. (2017) in their literature review have shown how the model of CE is often linked to the concepts of sustainability, sustainable development and the concept of Corporate Social Responsibility (CSR) whose categories and dimensions have been used in CE studies (Merli et al., 2017). In fact, if in the past researches CE have focused mainly on the environmental aspect, while the economic dimension of the model was taken into consideration mostly in the contributions of the practitioners and experts (Kirchherr et al., 2017). Instead, the most recent researches have tried to integrate more the social and economic features in line with the CE definition itself. In fact, in the CE model the relationship between the environment and economy is strong being the environment itself a contributor to the economic activities as "resource suppliers, waste assimilator, and source of utility" (Rizos et al., 2017). The close link with sustainability shows how the CE, through the application of the principles of sustainability, it is useful to offer practical solutions in CE activities (Merli et al., 2017).

Despite the concepts of CSR and CE belong to the same "umbrella concept" of sustainability (Esken et al., 2018), the two models do not overlap, because it cannot be affirmed that a CE practices is necessarily the environmentally desirable option (Kirchherr et al., 2017). In this direction, different researches are trying to understand the relation between the two concepts in a conceptual way, and how the companies are integrating their $\mathrm{CE}$ model in their corporate responsibility practices (Geissdoerfer et al., 2017). Leandro \& Paixao (2018) have explained as the two concepts can be considered as complementary to support the achievement of sustainable development that can help people, institutions and corporates to take on board the sustainable behaviours (Leandro \& Paixao, 2018): simplifying, the CE model is necessary to put in practice the deepest principles of CSR.

The studies aimed at understanding how the companies are integrating CE model in their activities is still limited and it is not clear how the CE activities must be reported within the company (Scarpellini et al., 2020).

From a theoretical point of view, the two concepts have been considered in different ways: for example, one view identified the $\mathrm{CE}$ as a condition to reach the sustainability objectives or there are studies that tried to explain how the CE model is a way to create environmental value (Geissdoerfer et al., 2017).

From a practical point of view, there are few contributions in providing evidence on which are the pragmatic actions and the activities started from companies to 
integrate the two paradigms (Geissdoerfer et al., 2017) and on which are the different benefits on Corporate Social Responsibility (CSR) performance and Corporate Sustainability (CS) (Yang et al., 2019).

For the purpose of this work, we focused on CSR that has been used in different studies aimed at understanding the implementation of CE in business context.

The CSR, as the CE, is a changing concept with no unique definition. CSR has been defined as the voluntary integration by firms of social and environmental issues in their activities and interaction with stakeholders (Amonarriz et al., 2019). Brondoni (2014) in his work talks about the CSR as the "relationship between economic, environment and social setting" (Brondoni, 2014). From this perspective, the CSR is a company's approach that puts social and environmental issues at the centre of their activities (Mosca \& Civera, 2017) capable to positively affect company's reputation and long term success. However, an opportunistic approach to CSR underpins an instrumental way of considering CSR just a driver to create competitive advantage. Indeed, CSR can be either extrinsically motivated or based on intrinsic reasons (Looser \& Wehrmeyer 2015; Wehrmeyer et al., 2020). Extrinsic motivations are often instrumentally-driven since they are aimed at increasing the shareholder value, while intrinsic motivations arise from the idealistic conviction that acting in a certain way is the right thing to do. Extrinsic CSR is often conceived by managers as a market-driven opportunities and is aimed at external recognition (Matten \& Moon, 2008) and competitive goals attainment. It always manifests in the adoption of certified management systems and accountability tools, such as social report, sustainability report or integrated report (Cassimon et al., 2015). By contrast, intrinsic CSR rests on idealistic motivations underpinning the behavior of companies that are characterized by a responsible conduct and a purpose-driven business culture, thus making CSR a moral duty (Visser, 2011; Story \& Neves 2015; Graafland \& van de Ven, 2006; Del Baldo, 2013) that is operationalized in the absence of a formalized CSR agenda and without implementing management system or CSR reports ("walking the talk"). However, the difference between extrinsic and intrinsic CSR is often very difficult to understand and some authors advocate that the extrinsic and the intrinsic motive for CSR could be integrated (Constantinescu \& Kaptein, 2020). Contributions in this research area address attention on the relationship between "walking" and "talking" CSR, as is typically found in the injunction to "walk the talk." This expression suggests that CSR communication and CSR practices should align (Schoeneborn et al., 2019).

A growing number of proponents advocate the effective incorporation of sustainability issues and CSR objectives into the framework of day-to-day management decision making. There is no one "right" way companies can practice CSR; many corporate CSR initiatives strive to positively contribute to the public, the economy or the environment (Lamberti \& Lettieri, 2009). Accordingly, CSR practices can cover a broad range objects, including stakeholder engagement, good corporate governance, transparecny in reporting (i.e. releasing CSR reports), operating ethically and carrying out a set of voluntary commitments to manage company's impact in the social, environmental, and economic fields (Hahn, 2013). A taxonomy of CSR practices (Schipper \& Gilbert Silvius, 2017), has been traced considering different perspectives and stakeholders. Key business practices for CSR include, among others: environmental policies (i.e. materials policy of reduction, 
reuse and recycling, waste management, energy conservation); public dialogue and disclosure; product stewardship; support for education and job training programmes; direct involvement in community projects; fair remuneration; effective communication; learning and development opportunities; equal employment opportunities; competent leadership; customer dialogue; use of local suppliers.

CSR contributes to make the firms 'activities more sustainable creating values for different groups of and external actors and attracting new investors and final user's interests (Salvioni \& Gennari, 2017). In this direction, the firms' behaviours must be oriented to minimize the impacts of their business actions in their area of activities and in the same time they must contribute to the well-being of the stakeholders in terms of environmental, cultural and social dimensions (Murdock \& Dolezal, 2018). The CSR concept involves three basic responsibilities (Economic, Social and Environmental) towards a large group of internal and external stakeholders, that includes economic and social actors (Gray et al., 1996). CSR brings to look at the company from the perspective of the society as a whole (Freeman \& Dmytriyev, 2017 ) and the positive relationships established with the stakeholders can provide a sustainable development approach in the long run (Salvioni \& Gennari, 2019).

In a context in which the CE model is taking root, the application of CSR approach is important for enterprises and may provide different advantages on different aspects (Stoyanova, 2019). Some studied have indeed used CSR reports as a source to investigate the adherence of companies to this new model. The $\mathrm{CE}$ activities implemented by companies that is usually analysed in terms of "Triple Bottom line" of sustainability (Scarpellini et al., 2020), but the topic on how CSR and CE are related, is almost still unexplored.

Accordingly, the focus of this work is to collect the main contribution of scholars and practitioners to understand which are the main studies that have been conducted and the main trends about this recent topic.

\section{Methodology}

\subsection{Research Questions}

To investigate the relation between CE and CSR, a simplified version of the structured literature review proposed by Massaro et al. (2016) has been conducted to answer to the following questions:

RQ1. Which are the main approaches identified by the literature on how the companies incorporate the CE concept in their CSR practices?

RQ2. Which methodologies have been applied by the authors to analyse the topic?

RQ3. Which future research can be developed to contribute to the expansion of this topic?

As stated by Massaro et al. (2016), the structured literature review is an useful method to study the literature available on a specific topic and in particular "to develop insights, critical reflections and exposing insightful and impactful future research paths", that can guarantee the "validity and reliability" of the research itself (Massaro et al. 2016). 
To perform a short literature review on the approaches of companies in integrating the CE concept in the sustainability practices, a computer search by means of Scopus and Web of Science databases was conducted. We included in the research the works available in the dataset using combination of keywords "Circular economy" and "CSR", with no time restrictions and including all the subject areas. The selection of these keywords is motivated by the need to provide insights focused on the relation and complementarity between the two models, being the social dimension little explored in the CE model (D'Amato et al., 2017). The research incorporates the works available in April 2020. We obtained a dataset of the works available in the two-search engine with all the information about the publications. Based on this obtained dataset, we analyzed the articles details presented by the Scopus and Web of Science statistics to provide descriptive information about the works: temporal and geographical distribution of the articles, type of publications and publication platform. Additionally, an analysis of the abstracts of the publications have been conducted to identify the works that are more in line with the objectives of our work and could provide an answer to our research questions.

In summary, the stages in the literature selection process were carried out as follow:

- data collection searching the keywords in the two databases (including the title and the abstract);

- unification of the databases and elimination of the works that appear twice;

- analysis of the publication details based on the information available in the Web of Science and Scopus records;

- analysis of the abstracts and keywords of the obtained dataset;

- exclusion of the works that do not include the words CSR and CE considering the titles, abstract and keywords.

- evaluation of all the abstracts to eliminate the ones that were not in line with the purpose of the literature review.

The selected sample includes all typology of researches: review, journal articles and proceeding papers. The conference proceedings have been included to catch the emerging trends in this research field. To select the articles more coherent and that could provide direct answer to our RQs, we read the full text of the works. Reading the articles, the publications considered not in line with the topic investigated have been excluded. In particular, have been excluded:

i) the works not aimed at identifying the approaches of companies about the inclusion of CE strategies in their CSR activities;

ii) the papers intended at analyzing just the CE concept or the CSR not in relation;

iii) the researches aimed at describing the results of a particular project.

Finally, two works have been excluded being that they were not available online.

As the last step of the literature review, the articles in line with the RQs have been listed and the main findings have been discussed to identify which are the main approaches to this new topic.

\section{Results and Discussions}


In all, the articles that come out from the research using the two databases were 32 showing as still the research about this topic is still limited to a limited number of works. The results of the research are shown in Table 1.

Table 1: Literature Search on the Main Search Engines

\begin{tabular}{|l|c|c|}
\hline Keywords & \multicolumn{2}{|c|}{ Data base } \\
\hline & Scopus & $\begin{array}{c}\text { Web of } \\
\text { Science }\end{array}$ \\
\hline Circular Economy [AND] CSR & 20 & 22 \\
\hline Total & \multicolumn{2}{|c|}{44} \\
\hline $\begin{array}{l}\text { Elimination of the duplication of the } \\
\text { articles }\end{array}$ & \multicolumn{2}{|c|}{12} \\
\hline Total & $\mathbf{3 2}$ \\
\hline $\begin{array}{l}\text { Articles considered coherent with the } \\
\text { RQs }\end{array}$ & $\mathbf{8}$ \\
\hline
\end{tabular}

Source: our elaboration.

Since the research on the databases has been conducted with no time restriction, we can see as the first works available exploring this topic date back to the 2009 and the topic started to became popular in 2018 (Fig. 1).

\section{Figure 1: Publication Trend}

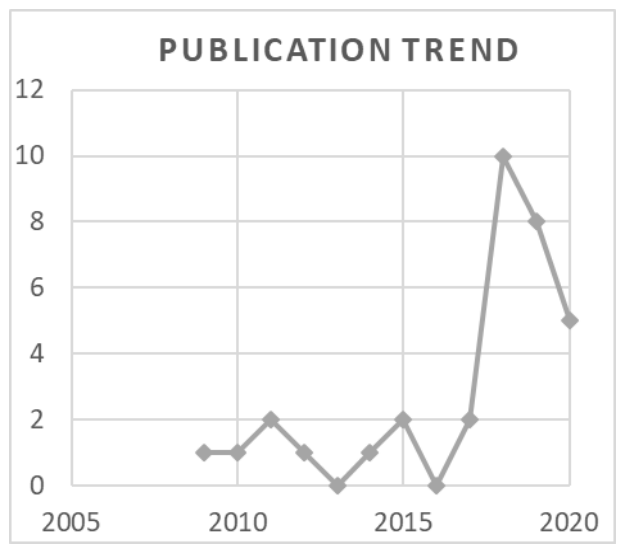

Source: our elaboration based on Web of Science and Scopus records.

The topic has been explored more in the Chinese and Italian literature, and other source of the works are Spain, India, and Netherland (Fig. 2). 
Figure 2: Geographical Distribution of the Works

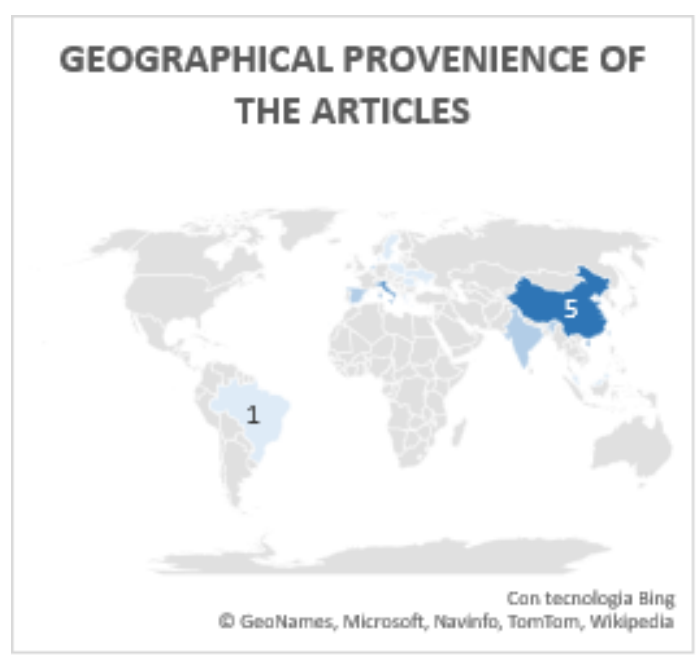

Source: our elaboration based on Web of Science and Scopus records.

Most of the literature available is composed by articles published in journals, while the 6 articles are works presented during conferences (Fig. 3).

Figure 3: Document Type

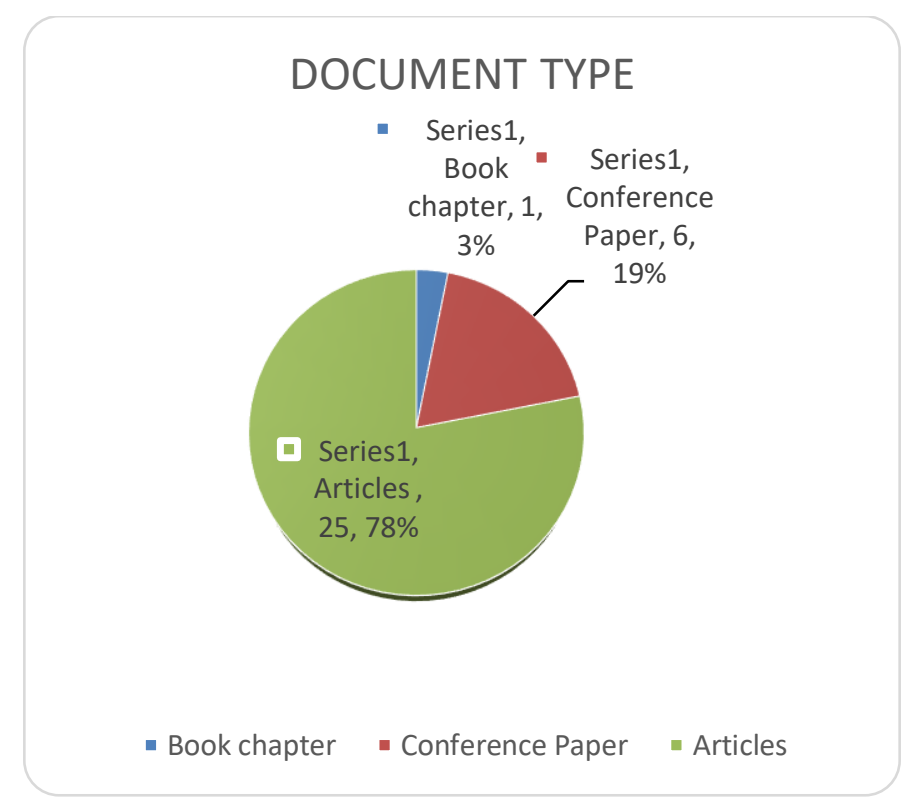

Source: our elaboration based on Web of Science and Scopus records.

The prevalent platforms of publication are journals dedicated to cleaner production, sustainability issues, environmental management and business strategies (Fig. 4). 


\section{Figure 4: Publication Platform}

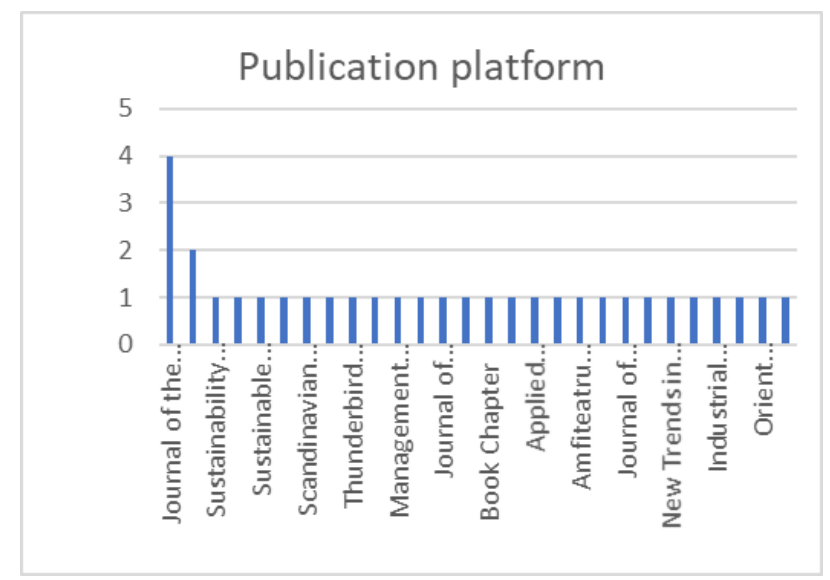

Source: our elaboration based on Web of Science and Scopus records.

As it has been showed in the previous section, the works that have been selected as relevant to answer the RQs available in the two databases are 8, showing as this topic is recent and need to be researched more. This is motivated by the fact that the concept of CE itself is a new concept, and the conceptualization of the model dates back just in 2012, with the definition of the Ellen MacArthur foundation. It is clear how the CE contextualization and sustainable related practices is still almost an unexplored and very recent trend.

The next table synthetize the profile of the works selected (Table 2).

The different articles approach to this topic in different ways: while some authors have treated transversally the relation of the two models, some authors have tried to provide a direct contribution about the topic, with regards both to the theoretical aspects and point of view of the activities carried out by the companies.

Yang et al. (2019) have tried to explain the influences of the CE and reverse activities on CSR performance, concluding that there is a complementarity of effects between the activities and positive effects on CSR performance. Cui \& Jiao (2014) studied the CSR in industrial cluster in CE perspective and conclude that can be divided in 4 responsibilities: i) legal, moral, strategic social and charitable responsibility (Cui \& Jiao, 2014).

Some studies have indeed investigated the link between the CE model with strategic CSR (Esken et al., 2018; Camilleri, 2018). Interesting is the work of Esken et al. (2018) who - studying the multinational in relation to the application of CE using the data from CSR reports - provide a contribution especially with regard to the theoretical conceptualization and integration of the two concepts. They tried to delineate the points of contact between the strategic CSR and the CE activities. According to them the two approaches overlap if we consider the three dimension "environmental, social and economic"; however, in the case of CE the three dimension are interconnected and necessary to achieve the benefits in each dimension (Esken et al., 2018). Furthermore, the CE can be considered as a more complete version of the strategic CSR which "winners" are the economic system in general and the natural capital (Esken et al., 2018). 
Table 2: Profiles of the Selected Articles

\begin{tabular}{|c|c|c|c|c|}
\hline Information about the article & Year & Journal & Keywords & Methodology \\
\hline $\begin{array}{l}\text { Dynamic capabilities and environmental } \\
\text { accounting for the circular economy in } \\
\text { business } \\
\text { Authors: Scarpellini, S., Marin-Vinuesa., } \\
\text { L., Portillo-Tarragona, P. }\end{array}$ & 2020 & $\begin{array}{l}\text { Economics- } \\
\text { Sustainability } \\
\text { Accounting, } \\
\text { Management and } \\
\text { Policy Journal } \\
\end{array}$ & $\begin{array}{l}\text { Stakeholders, Circular } \\
\text { economy, Corporate } \\
\text { finance, Environmental } \\
\text { management accounting, } \\
\text { Dynamic capabilities }\end{array}$ & $\begin{array}{l}\text { Quantitative- } \\
\text { Survey }\end{array}$ \\
\hline $\begin{array}{l}\text { Complementarity of circular economy } \\
\text { practices: and empirical analysis of Chinese } \\
\text { manufacturers } \\
\text { Authors: Yang, Y., Chen, L., Jua, F., Хu, Z. }\end{array}$ & 2018 & $\begin{array}{l}\text { International Journal } \\
\text { of Production } \\
\text { Research }\end{array}$ & $\begin{array}{l}\text { Circular economy, } \\
\text { complementarity, eco- } \\
\text { design, reverse } \\
\text { activities, systems } \\
\text { theory, secondary data }\end{array}$ & Quantitative \\
\hline $\begin{array}{l}\text { Responsible Luxury Development: A study } \\
\text { on Luxury companies's CSR, Circular } \\
\text { Economy, and Entrepreneurship } \\
\text { Authors: Donato, C., Amatulli, C., De } \\
\text { Angelis, M. }\end{array}$ & 2018 & $\begin{array}{l}\text { Environmental } \\
\text { Footprints and Eco- } \\
\text { Design of Products } \\
\text { and Processes }\end{array}$ & $\begin{array}{l}\text { Luxury, CSR, } \\
\text { Sustainability, Circular } \\
\text { economy, } \\
\text { Entrepreneurship, } \\
\text { Environment, } \\
\text { Employees, Society. }\end{array}$ & $\begin{array}{l}\text { Qualitative- } \\
\text { Case Studies }\end{array}$ \\
\hline $\begin{array}{l}\text { Circular economy in corporate } \\
\text { sustainability strategies: A review of } \\
\text { corporate sustainability reports in the fast- } \\
\text { moving consumer goods sector } \\
\text { Authors: Stewart R. Niero M. }\end{array}$ & 2018 & $\begin{array}{l}\text { Business Strategy and } \\
\text { the Environment }\end{array}$ & $\begin{array}{l}\text { CSR report, food and } \\
\text { beverage, household, } \\
\text { packaging, sustainable } \\
\text { development }\end{array}$ & $\begin{array}{l}\text { Qualitative- } \\
\text { Analysis of } \\
\text { Reports }\end{array}$ \\
\hline $\begin{array}{l}\text { Maximizing the value of waste: Form waste } \\
\text { management to the circular economy. } \\
\text { Authors: Romero-Hérnandez, O., Romero, } \\
\text { S. }\end{array}$ & 2018 & $\begin{array}{l}\text { Thumderbird } \\
\text { International Business } \\
\text { Review }\end{array}$ & $\begin{array}{l}\text { Business opportunities, } \\
\text { Waste Management, } \\
\text { Circular economy }\end{array}$ & $\begin{array}{l}\text { Qualitative- } \\
\text { Interviews }\end{array}$ \\
\hline $\begin{array}{l}\text { CSR as a signpost for circular economy } \\
\text { Authors: Esken, B., Franco-Garcìa, M., } \\
\text { Fisscher., O. }\end{array}$ & 2018 & $\begin{array}{l}\text { Management Research } \\
\text { Review }\end{array}$ & $\begin{array}{l}\text { CSR, MNCs, Varieties } \\
\text { of capitalism, Corporate } \\
\text { social responsibility, } \\
\text { Circular economy, } \\
\text { Strategic CSR, } \\
\text { Multinational } \\
\text { corporations, VOC, } \\
\text { Business ethics and } \\
\text { sustainability } \\
\end{array}$ & Mixed Methods \\
\hline $\begin{array}{l}\text { Closing the Loop for Resource Efficiency, } \\
\text { Sustainable Consumption and Production: } \\
\text { A Critical Review of the Circular Economy } \\
\text { Author: Camilleri, } M \text {. }\end{array}$ & 2018 & $\begin{array}{l}\text { International Journal } \\
\text { of Sustainable } \\
\text { Development }\end{array}$ & $\begin{array}{l}\text { Circular Economy, } \\
\text { Resource Efficiency, } \\
\text { Corporate Sustainability, } \\
\text { Creating Shared Value, } \\
\text { Corporate Social } \\
\text { Responsibility, Strategic } \\
\text { CSR, Stakeholder } \\
\text { Engagement, Social } \\
\text { Responsibility, } \\
\text { Recycling Resources, } \\
\text { Reusing Resources, } \\
\text { Reducing Resources. }\end{array}$ & $\begin{array}{l}\text { Qualitative- } \\
\text { Content analysis }\end{array}$ \\
\hline $\begin{array}{l}\text { Industrial Cluster Development and Social } \\
\text { Responsibility: From Circular Theory } \\
\text { Perspective } \\
\text { Authors: Cui, Y., Jiao, H. }\end{array}$ & 2014 & $\begin{array}{l}\text { Applied Mechanics } \\
\text { and Materials }\end{array}$ & $\begin{array}{l}\text { Circular Economy, } \\
\text { Enterprise, Industrial } \\
\text { Cluster, Social } \\
\text { Responsibility }\end{array}$ & Quantitative \\
\hline
\end{tabular}

Source: our elaboration.

Other points of contact concern the competitive advantage obtainable by the companies - which in the case of CSR is explicit while in the case of the CE is implicit in the objective of the model which is "generating efficiency and innovation" - and the other contact point is the perspective of creating long-term benefits (Esken et al., 2018). From the point of view of the activities that can be undertaken, a common practice is the use of renewable resources and the reuse procedures, that are the starting point for the implementation of CE paradigm (Donato et al., 2019).

An interesting contribution is the study conducted by Steward et al. (2018), that examined the topic analysing the CSR reports of 46 companies. According to them, 
the implementation of circular strategies by the companies remains very limited, and the model itself is perceived as a vision rather than a true and proper strategy to be implemented (Steward et al., 2018). As shown in their study, most of the companies have not clearly defined their CE activities and identified this new model only transversely. Just 17 companies' reports clearly share the information relating to the change undertaken by the companies in this sense. Most of the cited activities are the reduction of waste, the use of renewable energy and to a lesser extend the eco-design (just 8 companies and most of activities are just related to the packaging design). Furthermore, it has been highlighted how many activities are still implicit and one of the main reasons is the limited use of performance indicators (Steward et al., 2018). The performance indicators are in fact used by a minority of companies. One interesting evidence is that the companies have entered intro collaborations with external partners to start a dialogue to discuss the role of each in CE context (Steward et al., 2018).

Scarpellini et al. (2020) tried to investigate how CE systems were introduced within companies in relation to the level of CSR implemented. In general, the study revealed a positive relationship between CE activities and the level of development of the CSR (Scarpellini et al., 2018). They show as a good level of CSR influences the adoption of CE activities, especially on the aspects of communication with stakeholders.

Other studies, show as the companies that use CSR or sustainability reports not mention the benefits from some $\mathrm{CE}$ related activities (for example waste management activities), and actually companies could start to formalize these activities in order to confirm their effort in implementing circular economy model (Romero et al., 2018).

\section{Conclusions, Limitations and Emerging Issues}

This work was aimed at identifying the approaches used by literature on how the companies are integrating the CE activities in CSR practices. As the limited number of the papers have shown, the topic needs to be deepen investigated but analysing the papers some key features of how the literature is approaching to the theme (RQ1) can be cited. While the CE model started to become popular in the research panorama since 2000's (D'Amato et al., 2017), the studies about the integration of CE model in sustainable practices became popular only after 2018. Some studies tried to directly identify the links between the two concepts in theoretical terms and practical ones, while other ones tried to classify which are the approaches of companies analysing their CSR reports. Indeed, other studies attempted to pinpoint the effects of CE on CSR performance of the companies. Some researchers have analysed this relation in their works transversally. The methodologies used (RQ2) are both qualitative (using case studies methodology, above all the analysis of CSR reports and interviews) the and quantitative, especially using surveys.

From the analysis of the papers, some aspects of the topics that need to be researched properly have emerged (RQ3). First of all, the topic itself need to be investigate more in order to identify if the companies are "formally" integrating the CE model in their business sustainability strategies, with special focus on which is the sustainability relevance of CE. Furthermore, more studies can be addressed to develop a method to evaluate $\mathrm{CE}$ activities in relation to the sustainability efforts of 
companies. It could be interesting to focus more on the different forms of $\mathrm{CE}$ and understand if this model is becoming part of the company's strategies. Also, future researches may be oriented to investigate which is the role of external actors in influencing the implementation of CE practices in the sustainability agenda. Another thematic that could be deepen is the relation of CE and CSR concepts with other models that push businesses towards an environmental and social oriented approach.

It could be interesting to study the relation of the emerging ideas of CE and CSR with the GE (Green Economy) as one of most comprehensive models that includes different concepts related to the sustainable evolution (D'Amato et al., 2017). In particular, the study of these links both from a theoretical point of view and with reference to the strategies implemented by the companies could contribute to look at the concepts in a unified way and clarify the relations in terms of integration of the concepts and their applications. The aim of this literature review was to give a first glimpse to the topic using the databases Scopus and Web of Science. The few availability of the works shows a need of future research; however, this study can be expanded by using other databases, for example Google Scholar, that provides contributions from a comprehensive variety of fields and sources, or integrating the study using additional keywords. In fact, we have used strict criteria in the selection of the keywords (in this CSR and CE) but going ahead through future research steps may be accepted other works that refer to other sustainability-related concepts.

\section{Bibliography}

Bai, C., Sarkis, J., \& Dou, Y. (2015). Corporate Sustainability Development in China: Review And Analysis. Industrial Management \& Data Systems, 115(1), 5-40.

https://dx.doi.org/10.1108/IMDS-09-2014-0258

Bioeconomy, A. (2012). Innovating for Sustainable Growth: A bioeconomy for Europe. Industrial Biotechnology. Published Online:13 Apr 2012.

https://dx.doi.org/10.1089/ind.2012.1508

Blumberga, S., \& Saulīte, A. (2017). Corporate Social Responsibility and Consumers' Waste Sorting Habits. In CBU International Conference Proceedings, (5), 51-56.

https://dx.doi.org/10.12955/cbup.v5.901

Brondoni, S. M. (2014). Global Capitalism and Sustainable Growth. From Global Products to Network Globalisation. Symphonya. Emerging Issues in Management (symphonya.unimib.it), (1), 10-31.

http://dx.doi.org/10.4468/2014.1.02brondoni

Calvo, S., Morales, A., \& Zikidis, Y. (2017). Social and Solidarity Economy: the World's Economy with a Social Face. Taylor \& Francis.

Camilleri, M. A. (2018). Closing the Loop for Resource Efficiency, Sustainable Consumption and Production: A Critical Review of The Circular Economy. Sustainable Consumption and Production: A Critical Review of the Circular Economy.

https://dx.doi.org/10.1504/IJSD.2018.100802

Caputo, D., Paiano, A., \& Foltynowicz, Z. (2019). Corporate Social Responsibility For Industry 4.0. The Case Study of The Italian Company Operating in Poland. New Trends in Sustainable Business and Consumption, 152-158 Basiq International Conference.

http://basiq.ro/papers/2019/Corporate Social_Responsibility for_Industry 4.0. The Case Study of the Italian_Company_Operating in Poland.pdf 
Cassimon, D., Engelen, P.J., \& Van Liedekerke, L. (2016). When do Firms Invest in Corporate Social Responsibility? A Real Option Framework. Journal of Business Ethics, 137(1), 15-29.

http://dx.doi.org/10.1007/s10551-015-2539-y

Constantinescu, M., \& Kaptein, M. (2020). Virtue Ethics and CSR: The Two Sides of Sustainable Organizational Performance. In Wehrmeyer, W., Looser, S., \& Del Baldo, M. (eds.), Intrinsic CSR and Competition. Doing well amongst European SMEs. Cham, Switzerland: Palgrave MacMillan. https://doi.org/10.1007/978-3-030-21037-3_7

Cui, Y., \& Jiao, H. (2014). Industrial Cluster Development and Social Responsibility: from Circular Theory Perspective. In Applied Mechanics and Materials, 483, 574-577. Trans Tech Publications Ltd.

http://dx.doi.org/10.4028/www.scientific.net/AMM.483.574

D’Amato, D., Droste, N., Allen, B., Kettunen, M., Lähtinen, K., Korhonen, J., ... \& Toppinen, A. (2017). Green, Circular, Bio Economy: A Comparative Analysis of Sustainability Avenues. Journal of Cleaner Production, 168, 716-734.

http://dx.doi.org/10.1016/j.jclepro.2017.09.053

Del Baldo, M. (2013). Values-based Enterprises: the Good Practices of Italian SMEs, Passionately Committed to People, Environment and Community. In Bruni, L, \& Sena, B. (eds.), The Charismatic Principle in Social Life, Routledge (pp. 112-150). Taylor \& Francis, London.

http://dx.doi.org/10.4324/9780203077641

Donato, C., Amatulli, C., \& De Angelis, M. (2019). Responsible Luxury Development: A Study on Luxury Companies' CSR, Circular Economy, and Entrepreneurship, Sustainable Luxury, 21-38. Springer, Singapore.

http://dx.doi.org/10.1007/978-981-13-0623-5_2

Doni, F., Corvino, A., \& Martini, S. B. (2019). Servitization and Sustainability Actions. Evidence from European Manufacturing Companies. Journal of Environmental Management, 234, 367-378. http://dx.doi.org/10.1016/j.jenvman.2019.01.004

EC (2015). Closing the Loop - an EU Action Plan for the Circular Economy. Communication from the Commission to the European Parliament, the Council, the European Economic and Social Committee and the Committee of the Regions. COM/2015/0614.

Ellen MacArthur Foundation, (2012). E. M. Towards the Circular Economy: economic and business rationale for an accelerated transition. Isle of Wight: Ellen MacArthur Foundation.

Esken, B., Franco-García, M. L., \& Fisscher, O. A. (2018). CSR Perception as a Signpost for Circular Economy. Management Research Review, 41(5), 586-604.

https://dx.doi.org/10.1108/MRR-02-2018-0054

Freeman, R. E., \& Dmytriyev, S. (2017). Corporate Social Responsibility and Stakeholder Theory: Learning from each other. Symphonya. Emerging Issues in Management (symphonya.unimib.it), (1), $7-15$.

http://dx.doi.org/10.4468/2017.1.02freeman.dmytriyev

Geissdoerfer, M., Savaget, P., Bocken, N. M., \& Hultink, E. J. (2017). The Circular Economy-A New Sustainability Paradigm? Journal of Cleaner Production, 143, 757-768.

https://dx.doi.org/10.1016/j.jclepro.2016.12.048

Graafland, J.J., \& van de Ven, B. (2006). Strategic and Moral Motivation for Corporate Social Responsibility. Journal of Corporate Citizenship, 22, 111-123. http://dx.doi.org/10.9774/GLEAF.4700.2006.su.00012.

Gray, R., Owen, D., \& Adams, C. (1996). Accounting \& accountability: changes and challenges in corporate social and environmental reporting. New Jersey: Prentice Hall.

Hahn, R. (2013). ISO 26000 and the Standardization of Strategic Management Processes for Sustainability and Corporate Social Responsibility. Business Strategy and the Environment, 22(7), 442-455.

http://dx.doi.org/10.1002/bse.1751 
Hens, L., Block, C., Cabello-Eras, J. J., Sagastume-Gutierez, A., Garcia-Lorenzo, D., Chamorro, C., \& Vandecasteele, C. (2018). On the Evolution of "Cleaner Production" as a Concept and a Practice. Journal of Cleaner Production, 172, 3323-3333.

http://dx.doi.org/10.1016/j.jclepro.2017.11.082

Hogeboom, R. J., Kamphuis, I., \& Hoekstra, A. Y. (2018). Water Sustainability of Investors: Development and Application of an Assessment Framework. Journal of Ccleaner Production, 202, 642-648.

http://dx.doi.org/10.1016/j.jclepro.2018.08.142

Hui., Li (2010). A study of the Accounting Information Disclosure Mode of Corporate Social Responsibility in China Based on Circular Economy. Orient Academic Forum.

http://dx.doi.org/10.1108/SAMPJ-09-2014-0057

Hyytiä, A. (2014). Sustainable Development-International Framework-Overview and Analysis in the Context of Forests and Forest Products with a Stakeholder View-A Literature Review. In Scandinavian Forest Economics: Proceedings of the Biennial Meeting of the Scandinavian Society of Forest Economics (2014), 1334-2016-103873, 63-69.

http://dx.doi.org/10.22004/ag.econ.199233

Ingulfsvann, A. S. (2019). What Does the Brand Tell Us?-Sustainability and Responsibility In A Circular Perspective. Journal of Cleaner Production, October 2019, 246: 118993.

http://dx.doi.org/10.1016/j.jclepro.2019.118993

Jurišová, V. (2019). Environmental Awareness of the Zero Waste Concept and the Possibilities for Its Implementation within the CSR Strategy in Slovak Business Entities. In European Conference on Innovation and Entrepreneurship, 452-XIX. Academic Conferences International Limited.

http://dx.doi.org/10.34190/ECIE.19.173

Karagiannis, I., Vouros, P., Skouloudis, A., \& Evangelinos, K. (2019). Sustainability Reporting, Materiality, and Accountability Assessment in the Airport Industry. Business Strategy and the Environment, 28(7), 1370-1405.

http://dx.doi.org/10.1002/bse.2321

Kirchherr, J., Piscicelli, L., Bour, R., Kostense-Smit, E., Muller, J., Huibrechtse-Truijens, A., \& Hekkert, M. (2018). Barriers To The Circular Economy: Evidence From The European Union (EU). Ecological Economics, 150, 264-272.

http://dx.doi.org/10.1016/j.ecolecon.2018.04.028

Kirchherr, J., Reike, D., \& Hekkert, M. (2017). Conceptualizing The Circular Economy: an Analysis of 114 Definitions. Resources, Conservation and Recycling, 127, 221-232.

http://dx.doi.org/10.1016/j.resconrec.2017.09.005

Kok, P., T. van der Wiele, R. McKenna, \& Brown, A. (2001). A Corporate Social Responsibility Audit

Within a Quality Management Framework. Journal of Business Ethics, 31, 285-297.

http:// 297. doi: 10.1023/A:1010767001610.

Krysovatyy, A., Zvarych, I., \& Zvarych, R. (2018). Circular Economy in the Context of Alterglobalization. Journal of International Studies, 11(4), 185-200.

http://dx.doi.org/10.14254/2071-8330.2018/11-4/13

Kuo, L., Yeh, C. C., \& Yu, H. C. (2012). Disclosure of Corporate Social Responsibility and Environmental Management: Evidence From China. Corporate Social Responsibility and Environmental Management, 19(5), 273-287.

http://dx.doi.org/10.1002/csr.274

Kuo, L., Yu, H. C., \& Chang, B. G. (2015). The Signals of Green Governance On Mitigation Of Climate Change-Evidence From Chinese Firms. International Journal of Climate Change Strategies and Management, 7, 154-171.

http://dx.doi.org/10.1002/csr.274

Lamberti, L. \& Lettieri, E. (2009). CSR Practices and Corporate Strategy: Evidence from a Longitudinal Case Study, Journal of Business Ethics, 87(2),153-168. 
http://10.1007/s10551-008-9876-z

Leandro, A., \& Paixao, S. (2018). Corporate Social Responsibility and Circular Economy: Two Ways, Same Destinations? An Outlook on Both Concepts And Cases From Portugal. In Proceedings of the Congrès avniR, Lille, Portugal.

Loiseau, E., Saikku, L., Antikainen, R., Droste, N., Hansjürgens, Pitkänen, K., Leskinen, P., Kuikman, P., \& Thomsen, M. (2016). Green Economy and Related Concepts. Journal of Cleaner Production, $139,361-371$.

http://dx.doi.org/10.1016/j.jclepro.2016.08.024

Looser, S., \& Wehrmeyer, W. (2015). Doing Well or Doing Good? Extrinsic and Intrinsic CSR in Switzerland. $U W F, 1-14$, published on line 14 August 2015, Berlin Heidelberg: Springer-Verlag.

http://dx.doi.org/10.1007/s00550-015-0360-9

Lorek, S., \& Fuchs, D. (2013). Strong Sustainable Consumption Governance - Precondition for a Degrowth Path? Journal of Cleaner Production, 38, 36-43.

http://dx.doi.org/10.1016/ j.jclepro.2011.08.008

Lu, Y. (2012). Study on the Development Plan of the Lanzhou Tourism Industry in Line with Circular Economy. In Proceedings of the 7th Euro-Asia Conference on Environment and CSR: Tourism, MICE, Hospitality Management and Education Session, 100-105.

Massaro, M., Dumay, J., \& Guthrie, J. (2016). On the Shoulders of Giants: Undertaking a Structured Literature Review in Accounting. Accounting, Auditing \& Accountability Journal, 29(5), 767-801. http://dx.doi.org/10.1108/AAAJ-01-2015-1939

Matten, D., \& Moon, J. (2008). 'Implicit' and 'Explicit' CSR: A Conceptual Framework for a Comparative Understanding of Corporate Social Responsibility. Academy of Management Review, 33(2), 404-424.

http://dx.doi.org/10.5465/amr.2008.31193458

Merli, R., Preziosi, M., \& Acampora, A. (2018). How do Scholars Approach the Circular Economy? A Systematic Literature Review. Journal of Cleaner Production, 178, 703-722.

http://dx.doi.org/10.1016/j.jclepro.2017.12.112

Mitra, A., \& Gaur, S. S. (2020). Does Environmental Concern Drive Asian Firms' Governance? Journal of Asia Business Studies, 14(4), 481-503.

http://dx.doi.org/10.1108/JABS-06-2019-0189

Mosca, F., \& Civera, C. (2017). The Evolution of CSR: An Integrated Approach. Symphonya. Emerging Issues in Management (symphonya.unimib.it), (1), 16-35.

http://dx.doi.org/10.4468/2017.1.03mosca.civera

Munda, G. (1997). Environmental Economics, Ecological Economics, and the Concept of Sustainable Development. Environmental Values, 6, 213-233.

http://dx.doi.org/ 10.3197/096327197776679158.

Murdock, A., \& Dolezal, N. (2018). Exploring Corporate Social Responsibility in a Social Business: The Workers Beer Company. Symphonya. Emerging Issues in Management (symphonya.unimib.it), (1), 91-103.

http://dx.doi.org/10.4468/2018.1.07murdock.dolezal

Murray, A., Skene, K., \& Haynes, K. (2015). The Circular Economy: An Interdisciplinary Exploration Of The Concept And Application In A Global Context. Journal of Business Ethics, 140(3), 369380.

http://dx.doi.org/10.1007/s10551-015-2693-2

Neumayer, E. (2003). Weak versus Strong Sustainability: Exploring the Limits of Two Opposing Paradigms (2nd ed.), Cheltenham, UK: Edward Elgar.

http://dx.doi.org/10.1787/9789264111318-en

OECD (2011). Towards Green Growth. OECD Publishing. 
Nuvaid, V., Sardar, S., \& Chakravarty, S. (2017). CSR as Investment: An Analysis of Ownership Structure and Firm Performance. In Current Issues in Economics and Finance (113-123). http://dx.doi.org/10.1007/978-981-10-5810-3_8

Pesce, M., Shi, C., Critto, A., Wang, X., \& Marcomini, A. (2018). SWOT Analysis of the Application of International Standard ISO 14001 in the Chinese Context. A case study of Guangdong Province. Sustainability, 10(9), 3196.

http://dx.doi.org/10.3390/su10093196

Pohlmann, C. R., Scavarda, A. J., Alves, M. B., \& Korzenowski, A. L. (2020). The Role of the Focal Company in Sustainable Development Goals: A Brazilian Food Poultry Supply Chain Case Study. Journal of Cleaner Production, 245, 118798.

http://dx.doi.org/10.1016/j.jclepro.2019.118798

Qin, Y., Harrison, J., \& Chen, L. (2019). A Framework for the Practice of Corporate Environmental Responsibility in China. Journal of Cleaner Production, 235, 426-452.

http://dx.doi.org/10.1016/j.jclepro.2019.06.245

Rajesh, R. (2020). Exploring the Sustainability Performances of Firms Using Environmental, Social, And Governance Scores. Journal of Cleaner Production, 247, 119600.

http://dx.doi.org/10.1016/j.jclepro.2019.119600

Rizos, V., Behrens, A., Kafyeke, T., Hirschnitz-Garbers, M., Ioannou, A. (2015). The Circular Economy: Barriers and Opportunities for SMEs. CEPS Working Documents.

Rizos, V., Tuokko, K., Behrens, A., (2017). The Circular Economy. A review of Definitions, Processes and Impacts. CEPS Research Report.

Romero-Hernández, O., \& Romero, S. (2018). Maximizing the Value of Waste: from Waste Management to the Circular Economy. Thunderbird International Business Review, 60(5), 757764. http://dx.doi.org/10.1002/tie.21968

Salvioni, D., \& Gennari, F. (2017). CSR, Sustainable Value Creation and Shareholder Relations. Symphonya. Emerging Issues in Management (symphonya. unimib. it), (1), 36-49.

http://dx.doi.org/10.4468/2017.1.04salvioni.gennari

Salvioni, D., \& Gennari, F. (2019). Stakeholder Perspective of Corporate Governance And CSR Committees. Symphonya. Emerging Issues in Management (symphonya. unicusano. it), (1), 28-39.

http://dx.doi.org/10.4468/2019.1.03salvioni.gennari

Scarpellini, S., Marín-Vinuesa, L. M., Aranda-Usón, A., \& Portillo-Tarragona, P. (2020). Dynamic Capabilities and Environmental Accounting for The Circular Economy in Businesses. Sustainability Accounting, Management and Policy Journal, 1-30.

http://dx.doi.org 10.1108/SAMPJ-04-2019-0150

Schmidt, F. C., Zanini, R. R., Korzenowski, A. L., Schmidt Junior, R., \& Xavier do Nascimento, K. B. (2018). Evaluation of Sustainability Practices in Small and Medium-Sized Manufacturing Enterprises In Southern Brazil. Sustainability, 10(7), 2460.

http://dx.doi.org/10.3390/su10072460

Schipper, R.P.J, \& Gilbert Silvius, A.J. (2017). A New Taxonomy on CSR Practices as Basis for a New Theory on CSR. International Journal of Sustainable Strategic Management, 5(4), 275.

http://dx.doi.org/10.1504/IJSSM.2017.10010120

Schoeneborn, D., Morsing, M., \& Crane, A. (2020). Formative Perspectives on the Relation Between CSR Communication and CSR Practices: Pathways for Walking, Talking, and T(w)alking. Business \& Society, 59(1), 5-33.

http://dx.doi.org/10.1177/0007650319845091

Stępień, M. M., \& Białecka, B. (2018). Selection of Criteria for Assesment of New Recovery Technologies Of Coal Combustion Products. International Multidisciplinary Scientific GeoConference: SGEM, 18(5.1), 793-800. 
Stewart, R., \& Niero, M. (2018). Circular Economy in Corporate Sustainability Strategies: A Review Of Corporate Sustainability Reports In The Fast-Moving Consumer Goods Sector. Business Strategy and the Environment, 27(7), 1005-1022.

http://dx.doi.org/10.1002/bse.2048

Story, J., \& Neves, P. (2015). When Corporate Social Responsibility (CSR) Increases Performance: Exploring the Role of Intrinsic and Extrinsic CSR Attribution. Business Ethics: A European Review, 24(2), 111-123.

http://doi.org/10.1111/beer.12084

Stoyanova, T. (2019). CSR Strategies Applied in Terms of Circular Economy. Economic Alternatives, (2), 263-274.

Székàcs, A. (2017). Environmental and ecological aspects in the overall assessment of bioeconomy. Journal of Agriculture and Environmental Ethics, 30, 153-170.

http://dx.doi.org/10.1007/ s10806-017-9651-1

Tomaselli, M.F., Hajjar, R., Ramòn Hidalgo, A.E., \& Fernàndez, V. (2017). The Problematic Old Roots of the New Green Economy Narrative: How Far Can it Take Us in Reimagining Sustainability in Forestry? International Forestry Review, 19(1), 1-13.

UNEP (2011). Towards a Green Economy: Pathways to Sustainable Development and Poverty Eradication.

http: www.unep.org/greeneconomy

USA (2012). National Bioeconomy Blueprint. Industrial Biotechnology, 8, 97-102.

http:// dx.doi.org/10.1089/ind.2012.1524

Visser, W. (2011). The Nature of CSR Leadership. Definitions, Characteristics and Paradoxes. CSR International Paper Series, 4, 1-10.

Vuţă, M., Cioacă, S. I., Vuţă, M., \& Enciu, A. (2019). An Empirical Analysis of Corporate Social Responsibility Effects on Financial Performance for Romanian Listed Companies. Amfiteatru Economic, 21(52), 607-622.

http://dx.doi.org/10.24818/EA/2019/52/607

Wehrmeyer, W., Looser, S., \& Del Baldo, M. (eds.) (2020). Intrinsic CSR and Competition. Doing Well amongst European SMEs. Cham, Switzerland: Palgrave MacMillan.

http://doi.org/10.1007/978-3-030-21037-3.

Yang, S., (2009). Corporate Social Responsibility in Environmental Protection: An Evaluation System and Promoting Mechanism in China, Proceedings for the 5th euro-asia conference on environment and corporate social responsibility: management science and engineering, PT II, 136-14).

http://dx.doi.org/10.1016/j.orgdyn.2015.12.005

Yang, Y., Chen, L., Jia, F., \& Xu, Z. (2019). Complementarity of Circular Economy Practices: an Empirical Analysis of Chinese Manufacturers. International Journal of Production Research, 57(20), 6369-6384.

https://dx.doi.org/10.1080/00207543.2019.1566664

\section{Notes}

${ }^{1}$ Bioeconomy is the least of the three concepts to identify with strong sustainability, while CE and GE are considered more oriented towards strong sustainability (Loiseau et al., 2016; D'Amato et al., 2017). 